\title{
THE EFFECT OF SELECTED PESTICIDES ON THE GROWTH OF ENTOMOPATHOGENIC FUNGI HIRSUTELLA NODULOSA AND BEAUVERIA BASSIANA
}

\author{
Cezary Tkaczuk', Marta Harasimiuk'1, Anna Król', Paweł K. Bereś² \\ 1 Department of Plant Protection and Plant Breeding, Siedlce University of Natural Sciences and Humanities, \\ ul. Prusa 14, 08-110 Siedlce, Poland, e-mail: tkaczuk@uph.edu.pl \\ 2 Institute of Plant Protection - National Research Institute, Regional Experimental Station, ul. Langiewicza 28, \\ 35-101 Rzeszów, Poland
}

Received: 2015.03.15

Accepted: 2015.06.02

Published: 2015.07.01

\begin{abstract}
The effect of three pesticides used in corn protection: Targa Super 05 (chizalofop-Pethyl), Roundup 360SL (glyphosate) and Karate Zeon 050CS (lambda-cyhalothrin), on the growth of entomopathogenic fungi Hirsutella nodulosa Petch and Beauveria bassiana (Bals.) Vuill. was evaluated under laboratory conditions. Fungi isolates were cultured on Sabouraud's medium with addition of pesticides at three different concentrations. H. nodulosa was more susceptible to pesticides than B. bassiana. The most inhibitory effect on tested entomopathogenic fungi showed chizalofop-P-ethyl herbicide. Lambda-cyhalothrin at the recommended field dose showed minor toxic effect on entomopathogenic fungi, which suggests the possibility of compatible use of this insecticide with biopesticides based on the tested species.
\end{abstract}

Keywords: pesticides, entomopathogenic fungi, corn protection.

\section{INTRODUCTION}

The European corn borer (Ostrinia nubilalis Hüb.) is currently considered the major corn pest. The greatest harmfulness of this species is recorded in regions of intensive corn cultivation, where caterpillars damage from $50 \%$ to $80 \%$ of plants at many plantations, in some cases even up to $100 \%$. Many factors, such as agrotechnical simplifications, monoculture of cereals, leaving crop residues, late winter plowing or the enlargement of the corn plantations favor the increase of $O$. nubilalis abundance [Bereś 2013]. Through the injuries serious pathogens entry into the plants, especially Fusarium fungi, which produce mycotoxins that are dangerous for humans and animals. Moreover, from the plants heavily damaged by pests poor quality grain and green mass yields are obtained.

Predominant method of $O$. nubilalis control in conventional corn cultivation is using chemical pesticides, however, the excessive applications of chemicals involve risk of negative impact of these substances on the environment and living organisms.

There is also a possibility of biological controlling of $O$. nubilalis like applying Trichogramma sp. - a useful insect, parasite of many butterfly species. This method involves the use of biopesticides (e.g. Trichoplus) containing living Trichogramma sp. chrysalises [Bereś 2013]. The previous research indicate also a possibility of using entomopathogenic fungi, especially from Beauveria and Isaria genera, to control O. nubilalis in corn cultivations [Bing and Lewis 1993, Kuźniar et al. 2012].

Entomopathogenic fungi are natural factors regulating the population of many insect species, including $O$. nubilalis. An interesting alternative to chemical methods may be the production of biopesticides based on these microorganisms [Bajan et al. 1992, Faria and Wright 2007]. They infect insects regardless of the type of their mouthparts. Contrary to the bacterial or viral infections, 
which occur by alimentary tract, fungal infection occurs as a result of enzymatic dissolution of the insect cuticle. In the body of infected arthropod develops hyphae, which causes the destruction of the internal organs, and thus the death of the infected individual [Bidochka and Khachatourians 1994]. Environment in which entomopathogenic fungi have best conditions for survival and development is the soil, where these microorganisms frequently cause natural arthropod mycoses [Miętkiewski et al. 1997, Tkaczuk 2008].

One of the important issues of integrated plant protection is to understand the impact of chemical pesticides on entomopathogenic fungi in order to determine the possibilities of their combined use with pesticides in plant protection.

As it is known from the literature pesticides can have a negative effect on the growth, sporulation and pathogenicity of entomopathogenic fungi [Vänninen and Hokkanen 1988, Majchrowicz and Poprawski 1993, Miętkiewski et al. 1995 and 1996, Bajan and Kmitowa 1997, Tkaczuk 2008, Tkaczuk et al. 2012].

The aim of this study was to evaluate the effect of selected pesticides used in corn protection on growth of two entomopathogenic fungi Hirsutella nodulosa isolated from $O$. nubilalis larvae and Beauveria bassiana isolated from soil of the corn plantation inhabited by the European corn borer.

\section{MATERIAL AND METHODS}

The effect of tree pesticides ( 2 herbicides: chizalofop-P-ethyl and glyphosate, and insecticide: lambda-cyhalothrin) on colony of entomopathogenic fungi (Hirsutella nodulosa and Beauveria bassiana) growth was evaluated under laboratory conditions. Details of the characteristics of the applied pesticides are presented in Table 1.

Hirsutella nodulosa strain was isolated from European corn borer (Ostrinia nubilalis) caterpillar derived from corn plantation cultivated in monoculture from Krzeczowice near Przeworsk (field belonging to the Regional Experimental Station of the Institute of Plant Protection - NRI in Rzeszów, south-eastern Poland). The Beauveria bassiana has been isolated by means of Galleria bait method from the soil collected on the corn field near Siedlce. Fungi were assigned to species according to their morphological features [Goetel and Inglis 1997, Hodge 2000]. The fungal isolates were cultured on Sabouraud's medium with addition of the aforementioned pesticides.

The medium was sterilized in an autoclave at $121{ }^{\circ} \mathrm{C}$ for 15 minutes. When the medium obtained $50-60{ }^{\circ} \mathrm{C}$ precise doses of pesticides were added. Subsequent concentration of pesticides in medium was obtained by dilution.

The tested pesticides were added to the medium in the following doses:

- A - 10 times higher than recommended field dose,

- B - recommended field dose,

- $\mathrm{C}-10$ times lower than recommended field dose.

As a control fungi cultures grown on medium without pesticides were used. The medium in Petri dishes with $9 \mathrm{~mm}$ diameter were inoculated with mycelium of one week cultures grown on Sabouraud's medium and then incubate at 22-23 ${ }^{\circ} \mathrm{C}$. Experiment was performed in four replications. Observations of colony growth were carried out every 5 days until the $20^{\text {th }}$ day of culturing by measuring the colony diameter (in millimeters). The results are presented as colony diameter size expressed as a percentage relative to the control.

\section{RESULTS}

Among the tested pesticides herbicide chizalofop-P-ethyl was the most toxic to the Hirsutella nodulosa. The dose (A) applied in a 10 times higher amount than recommended caused a complete inhibition of fungal growth (Table 2). In the same dose the growth of $H$. nodulosa colony

Table 1. Characteristics of pesticides used in the experiment

\begin{tabular}{|l|l|c|}
\hline \multicolumn{1}{|c|}{ Trade name of pesticide } & Active substance & $\begin{array}{c}\text { The recommended dose } \\
\text { (ml/g of formulation / 1 liter) }\end{array}$ \\
\hline \multicolumn{1}{|c|}{ Herbicides } \\
\hline Targa Super 05 EC & chizalofop-P-ethyl $-50 \mathrm{~g} / \mathrm{I}$ & $5 \mathrm{ml} / \mathrm{I}$ \\
\hline Roundup 360 SL & glyphosate $-360 \mathrm{~g} / \mathrm{I}$ & $10 \mathrm{ml} / \mathrm{I}$ \\
\hline \multicolumn{1}{|c|}{ Insecticide } & $0.8 \mathrm{ml} / \mathrm{I}$ \\
\hline
\end{tabular}


under glyphosate influence was possible but the growth of isolate started after 15 days of observation. After 20 days fungal colonies reached only $21.1 \%$ of the control colonies size (Table 2).

At the recommended field dose (B) herbicides chizalofop-P-ethyl and glyphosate after 20 days of experiment inhibited the fungal colony growth respectively by approximately $64 \%$ and $52 \%$. The tested herbicides strongly limited the growth of $H$. nodulosa on media with a 10 times lower than recommended concentration $(\mathrm{C})$ as well. After 20 days of observation colonies of fungus growing on media with $\mathrm{C}$ dose of herbicides chizalofop-Pethyl and glyphosate reached respectively $58,2 \%$ and $65,7 \%$ of the control colonies size.

Insecticide lambda-cyhalothrin tested in the experiment was less toxic to $H$. nodulosa compared to herbicides. After 20 days of observation fungal colonies growing on media supplemented with this insecticide at 10 times higher than recommended dose reached $46.5 \%$ of the control colonies diameter. On the same day of observation in the recommended field dose (B) lambda-cyhalothrin slightly inhibited the growth of the fungus (by $13,6 \%$ compared to the control) whereas at 10 times lower than recommended dose (C) it showed even slightly stimulating effect on the growth of the $H$. nodulosa colony (Table 3 ).

The pesticides tested in the experiment also affected the development of $B$. bassiana. The growth of this fungus depended crucially on the type of pesticide and its concentration in medium.

The study showed that among the tested pesticides most inhibitory effect on the growth of $B$. bassiana had chizalofop-P-ethyl herbicide, which used in 10 times higher than recommended dose caused complete inhibition of fungus growth (Table 4). The applied dose A of glyphosate also inhibited the growth of the tested fungus, but its influence was significantly weaker than the chizalofop-P-ethyl effect. The growth of $B$. bassiana colonies began after 10 days of observation, and after 20 days they reached $68 \%$ of the control colonies size (Table 4).

In a recommended field dose (B) chizalofopP-ethyl also strongly inhibited the $B$. bassiana growth, which began after 15 days of observation. On the $20^{\text {th }}$ day of growth fungal colonies reached $56.1 \%$ of the controls (Table 4 ). Glyphosate was significantly less toxic to B. bassiana. It started to grow after 10 days of observation and after 20 days fungal colonies grown on medium with pesticide addition were only $6,5 \%$ smaller than the control ones.

After 20 days of the experiment and at 10 times lower than recommended concentration (C) chizalofop-P-ethyl inhibited the fungal growth by $23,5 \%$ (Table 4 ). In the medium with glyphosate addition in dose C, B. bassiana have started to grow after 10 days of the experiment and after 20

Table 2. The size of Hirsutella nodulosa colonies grown on media with herbicides

\begin{tabular}{|c|c|c|c|c|c|}
\hline \multirow{2}{*}{$\begin{array}{c}\text { Active substance and concentration } \\
\text { of herbicides }\end{array}$} & \multicolumn{4}{|c|}{ The average size of colonies (\% relative to control) } \\
\cline { 3 - 6 } & & after 5 days & after 10 days & after 15 days & after 20 days \\
\hline \multirow{3}{*}{ Chizalofop-P-ethyl } & A & 0.0 & 0.0 & 0.0 & 0.0 \\
\cline { 2 - 6 } & B & $50.0 \pm 0.5$ & $55.7 \pm 0.6$ & $45.2 \pm 0.6$ & $36.6 \pm 1.3$ \\
\cline { 2 - 6 } & C & $72.2 \pm 0.5$ & $62.4 \pm 0.6$ & $53.4 \pm 0.5$ & $65.7 \pm 1.2$ \\
\hline \multirow{3}{*}{ Glyphosate } & A & 0.0 & 0.0 & $19.6 \pm 0.5$ & $21.1 \pm 0.5$ \\
\cline { 2 - 6 } & B & $55.6 \pm 0.6$ & $60.6 \pm 0.4$ & $54.5 \pm 0.3$ & $47.9 \pm 0.6$ \\
\cline { 2 - 6 } & C & $55.6 \pm 0.6$ & $55.7 \pm 0.6$ & $57.5 \pm 0.9$ & $58.2 \pm 1.2$ \\
\hline
\end{tabular}

A - 10 times higher than recommended field dose,

$\mathrm{B}$ - recommended field dose,

$\mathrm{C}-10$ times lower than recommended field dose

\pm- standard deviation

Table 3. The size of Hirsutella nodulosa colonies grown on media with insecticide lambda-cyhalothrin

\begin{tabular}{|c|c|c|c|c|c|}
\hline \multirow{2}{*}{$\begin{array}{c}\text { Active substance and concentration } \\
\text { of insecticide }\end{array}$} & \multicolumn{4}{|c|}{ The average size of colonies (\% relative to control) } \\
\cline { 3 - 6 } & A & after 5 days & after 10 days & after 15 days & after 20 days \\
\hline \multirow{3}{*}{ Lambda-cyhalothrin } & B & $61.1 \pm 0.5$ & $40.4 \pm 0.8$ & $33.9 \pm 0.9$ & $46.5 \pm 1.7$ \\
\cline { 2 - 6 } & C & $77.8 \pm 0.6$ & $82.6 \pm 0.3$ & $82.2 \pm 0.0$ & $86.4 \pm 1.5$ \\
\hline & & $96.1 \pm 0.9$ & $102.7 \pm 1.5$ & $105.2 \pm 1.5$ \\
\hline
\end{tabular}

Explanations as in Table 2. 
Table 4. The size of Beauveria bassiana colonies grown on media with herbicides

\begin{tabular}{|c|c|c|c|c|c|}
\hline \multirow{2}{*}{$\begin{array}{c}\text { Active substance and concentration } \\
\text { of herbicide }\end{array}$} & \multicolumn{5}{|c|}{ The average size of colonies (\% relative to control) } \\
\cline { 3 - 6 } & & after 5 days & after 10 days & after 15 days & after 20 days \\
\hline \multirow{3}{*}{ Chizalofop-P-ethyl } & A & 0.0 & 0.0 & 0.0 & 0.0 \\
\cline { 2 - 6 } & B & 0.0 & 0.0 & $52.7 \pm 1.4$ & $56.1 \pm 0.6$ \\
\cline { 2 - 6 } & C & $75.0 \pm 2.6$ & $66.3 \pm 0.3$ & $85.9 \pm 0.6$ & $76.5 \pm 1.3$ \\
\hline \multirow{3}{*}{ Glyphosate } & A & 0.0 & $45.4 \pm 1.2$ & $61.3 \pm 0.3$ & $68.0 \pm 0.8$ \\
\cline { 2 - 6 } & B & 0.0 & $70.1 \pm 0.8$ & $90.7 \pm 2.1$ & $93.5 \pm 1.3$ \\
\cline { 2 - 6 } & C & 0.0 & $73.9 \pm 0.3$ & $89.5 \pm 0.6$ & $73.9 \pm 1.0$ \\
\hline
\end{tabular}

Explanations as in Table 2.

days fungal colonies obtained on average $74 \%$ of the control colonies size (Table 4).

The insecticide lambda-cyhalothrin tested in the experiment was less toxic to $B$. bassiana than herbicides. On media supplemented with this insecticide at 10 times higher than recommended dose fungal colonies reached $78 \%$ of the control colonies size after 20 days of experiment. On $20^{\text {th }}$ day of observation lambda-cyhalothrin at recommended field dose slightly inhibited the fungal growth (at about 20.6\% compared to the control). On the same day of experiment insecticide at 10 times lower than recommended dose showed no negative effect on the size of $B$. bassiana colonies. It reached $99.7 \%$ of the control colonies diameter (Table 5).

\section{DISCUSSION}

The main factors limiting the ability of effective use of biopesticides based on entomopathogenic fungi in pest control are relatively poor knowledge of their biology as well as insufficient knowledge of the effect of environmental factors and impacts associated with human activities on growth and pathogenicity of these microorganisms, including the use of pesticides.

Most of laboratory research indicates a negative effect of pesticides on entomopathogenic fungi. These products can reduce growth, sporulation, spore germination and pathogenicity of these fungi [Bajan and Kmitowa 1997, Vanninen and Hokkanen 1988, Poprawski and Majchrowicz 1995, Miętkiewski et al. 1995 and 1996, Tkaczuk 2001].

According to Bajan and Kmitowa [1982, 1997], pesticides which are used in Poland do not eliminate the entomopathogenic fungi from the environment, however, some of them may limit the growth or impair pathogenicity of these organisms.

The reaction power depends on fungus species or its ecotype. Numerous laboratory studies indicated that the various fungal species, or even strains of the same species vary in susceptibility to pesticides [Bajan et al. 1992, Sapieha and Miętkiewski 1991/1992, Tkaczuk 2001, Tkaczuk et al. 2012].

The present study showed that most toxic effects on $H$. nodulosa and B. bassiana had chizalofop-P-ethyl herbicide applied at 10 times higher than recommended dose as well as at the recommended field dose. Among the tested herbicides relatively low inhibition of the fungi growth showed based on glyphosate Roundup 360 SL.

According to Tkaczuk and Miętkiewski [2001] herbicides Roundup (glyphosate) and Stomp (pendimethalin) at the dose 10 times higher than the recommended once completely inhibited the growth of Hirsutella aphidis. At recommended field concentration inhibitory effect of Roundup was less than effect of Stomp. Examining the growth of entomopathogenic fungi

Table 5. The size of Beauveria bassiana colonies grown on media with lambda-cyhalothrin insecticide

\begin{tabular}{|c|c|c|c|c|c|}
\hline \multirow{2}{*}{$\begin{array}{c}\text { Active substance and concentration } \\
\text { of insecticide }\end{array}$} & \multicolumn{4}{|c|}{ The average size of colonies (\% relative to control) } \\
\cline { 3 - 6 } & A & after 5 days & after 10 days & after 15 days & after 20 days \\
\hline \multirow{3}{*}{ Lambda-cyhalothrin } & B & $79.5 \pm 2.6$ & $78.9 \pm 0.6$ & $77.4 \pm 2.3$ & $78.0 \pm 1.2$ \\
\cline { 2 - 6 } & C & $95.9 \pm 1.6$ & $81.4 \pm 1.7$ & $71.9 \pm 1.3$ & $79.4 \pm 0.5$ \\
\hline
\end{tabular}

Explanations as in Table 2. 
on media containing herbicides that were used in orchards Miętkiewski et al. [1990] have found that glyphosate was the least toxic of the studied pesticides. Even on medium containing this herbicide at a 10 times higher than recommended dose, all tested fungal species (B. bassiana, Paecilomyces fumosoroseus and Verticillium lecanii) have grown.

Tested in this study insecticide Lambda-cyhalothrin was less toxic to $H$. nodulosa and $B$. bassiana than herbicides. Its recommended dose (B) inhibited the growth of the aforementioned fungal isolates of respectively $24.5 \%$ and $21.6 \%$ compared to control. Similar results about the impact of lambda-cyhalotrin to H. nodulosa isolated from European corn borer caterpillars were obtained by Tkaczuk et al. [2013]. Many authors indicate relatively small effect of insecticides on the growth and germination of entomopathogenic fungi compared to fungicides and herbicides [Miętkiewski et al. 1997, Tkaczuk et al. 2012 and 2013]

In this study H. nodulosa isolated from European corn borer caterpillars showed greater susceptibility to the tested pesticides than $B$. bassiana obtained from the soil. Examining the effects of selected insecticides on the growth of several entomopathogenic fungi species (e.g. Isaria farinosa, I. fumosorosea, Metarhizium anisopliae and Lecanicilium sp.) and H. nodulosa. Tkaczuk et al. [2013] found significantly greater susceptibility of this fungus to the tested pesticides than aforementioned species. Tkaczuk and Miętkiewski [2005] observed a difference in susceptibility to pesticides of four fungal species from Hirsutella genus pathogenic to phytophagous mites. Fungi $H$. necatrix and H. kirchneri isolated from eriophyid mite Abacarus hystrix were the most resistant to toxic effect of tested pesticides and $H$. nodulosa isolated from Tarsonemidae mite was the most susceptible.

It should be, however, emphasized that the laboratory research on fungi susceptibility to pesticides do not necessarily reflect the complex situation in field, where the interactions between fungi and pesticides could be modified by a number of biotic and abiotic factors.

A stronger effect of pesticides on entomopathogenic fungi under in vitro conditions, on the culture medium, compared with their effects in the soil may be due to the several reasons. Culture medium is characterized by high homogeneity and therefore, the precise distribution of active substance, which makes its impact on the fungus more rapid and more efficient, in comparison with heterogeneous soil environment. Furthermore, the particles of pesticide in soil may be bound by some of its ingredients. In particular organic matter, which is the main soil component responsible for adsorbing pesticides by the hydrobiotic reactions [Green and Karickhoff 1990].

Some studies indicate synergetic effects of entomopathogenic fungi and particular insecticide substances. Pelizza [2015] evaluating the efficacy of combinations between three insecticides (luphenuron, methoxyfenozid, rynaxypyr) and strains of Beauveria bassiana and Metarhizium anisopliae in the control of the pest grasshopper Ronderosia bergi found that combinations of those insecticides with tested fungi caused higher mortality to $R$. bergi nymphs than any of the individual agents used alone. It is suggested that the fungi could metabolize the insecticides compounds and used it as secondary nutrients. Another explanation of synergetic action of entomopathogenic fungi and particular insecticides is that within a toxic environment, the fungus could respond with an enhanced reproductive effort in the form of an increased conidia production [Pelizza 2015].

Hernandez et al. [2012] who evaluated the compatibility of flufenoxuron and azadirachtin with Beauveria bassiana against Tetranychus urticae larvae as the cause of more effective action of entomopathogenic fungi with this insecticides indicate the possibility that they can inhibit the formation of chitin in mite cuticle and facilitate the fungi penetration inside the arthropod.

Another research revealed, however, no or negative impact of insecticides on entomopathogenic fungi. Rashid et al. [2010], for example, found that insecticides: fipronil, pyriproxyfen and hexaflumuron significantly reduced the conidial germination of Metharizium anisopliae under laboratory conditions. Tested in this study insecticide lambda-cyhalothrin slightly reduced the size of fungal colonies, which make it suitable for compatible use with entomopathogenic fungi.

Finding the appropriate insecticides that enhance the pathogenicity of particular entomopathogenic fungi species, or at least not affect negatively on their action appears to be useful in integrated pest management. Compatible use entomopathogenic fungi and insecticides would allow apply chemical pesticides at lower concentrations. 


\section{CONCLUSIONS}

1. Most inhibitory effect on tested entomopathogenic fungi (Hirsutella nodulosa and Beauveria bassiana) among tested pesticides showed chizalofop-P-ethyl herbicide.

2. H. nodulosa isolated from European corn borer caterpillars was more susceptible to the presence of pesticides in medium than $B$. bassiana.

3. Lambda-cyhalothrin (Karate Zeon 050 CS) at the recommended field dose showed minor toxic effect on the tested entomopathogenic fungi, which suggests the possibility of compatible use of this insecticide with biopesticides based on those species.

\section{REFERENCES}

1. Bajan C., Fedorko A., Kmitowa A. 1992. Grzyby owadobójcze w integrowanej ochronie roślin. Mat. Konf. In: E. Niemczyk (Ed.) Materials from the Scientific Conference on biological control of pests in the programs of integrated methods "Entomopathogenic fungi in integrated protection of plants", Skierniewice, 32-39.

2. Bajan C., Kmitowa K. 1982. The effect of herbicides: Simazin 50. Avadex and Antyperz on four species of entomopathogenic fungi. Pol. Ecol. Stud. 8 (3), 489-497.

3. Bajan C., Kmitowa K. 1997. Thirty years studies on entomopathogenic fungi in the Institute of Ecology. PAS. Pol. Ecol. Stud. 23 (3-4), 133-154.

4. Bereś P. K. 2013. Studium nad doskonaleniem integrowanej ochrony kukurydzy przed Zachodnią kukurydzianą stonką korzeniową (Diabrotica vigifera vigifera LeConte) i omacnicą prosowianką (Ostrinia nubilalis Hbn.). Rozprawy Naukowe Instytutu Ochrony Roślin - Państwowego Instytutu Badawczego. Zeszyt 29. Poznań.

5. Bidochka M.J., Khachatourians G.G. 1994. Protein hydrolysis in grasshopper culticles by entomopathogenic fungal extracellulator proteases. J. Invertebr. Pathol. 63, 7-13.

6. Bing L.A., Lewis L.C. 1993. Occurrence of entomopathogen Beauveria bassiana (Balsamo) Vuillemin in different tillage regimes and in Zea mays L. and virulence towards Ostrinia nubilalis (Hübner). Agric. Ecosyst. Environ. 45, 147-156.

7. Faria M., Wraight S. 2007. Mycoinsecticides and Mycoacaricides: A compressive list with worldwide coverage and international classification of formulation types. Biol. Control. 43, 237-256.
8. Goettel M.S., Inglis G.D. 1997. Fungi: Hyphomycetes. In: L.A. Lacey (Ed.) Manual of Techniques in Insect Pathology, Academic Press, San Diego, USA, 213-249.

9. Green, R.E., Karickhoff S.W. 1990. Sorption estimates for modeling. In: H.H. Cheng (Ed.) Pesticides in the soil environment. Soil Science Society of America. Madison, 530, 79-101.

10. Hernandez M.M., Martinez-Villar E., Peace C., Perez-Moreno I., Marco V. 2012. Compatibility of the entomopathogenic fungus Beauveria bassiana with flufenoxuron and azadirachtin against Tetranychus urticae. Appl. Acarol. 58, 395-405.

11. Hodge A. 2000. Microbial ecology of the arbuscular mycorrhiza. FEMS Microbiol. Ecol. 32, 91-96.

12. Kuźniar T., Ropek D., Krysa A. 2012. Wykorzystanie grzyba owadobójczego Isaria fumosorosea do ograniczania szkodliwości omacnicy prosowianki (Ostrinia nubilalis Hbn.) w uprawie kukurydzy cukrowej. Prog. Plant Prot./Post. Ochr. Roślin. 52 (2), 354-359.

13. Majchrowicz I., Poprawski T.J. 1993. Effects in vitro of nine fungicides on growth of entomopathogenic fungi. Biocontrol Sci. Technol. 3, 321-336.

14. Miętkiewski R., Ignatowicz S., Górski R. 1996. Porównanie wpływu BioNEMTM, insektycydu pochodzenia roślinnego i wybranych insektycydów syntetycznych na wzrost grzybni grzybów owadobójczych. Pestycydy 1, 15-27.

15. Miętkiewski R., Miętkiewska Z., Sapieha A., Badowska-Czubik T. 1995. Wpływ herbicydów na patogeniczność grzybów entomopatogennych. Zesz. Nauk. WSRP w Siedlcach, 37, 179-184.

16. Miętkiewski R., Sapieha A., Miętkiewska Z. 1990. Wzrost grzybów owadobójczych na pożywkach zawierających herbicydy stosowane w sadownictwie. Acta Mycol. 25 (2), 35-50.

17. Miętkiewski R.T, Pell J.K, Clark S.J. 1997. Influence of pesticides use on the natural occurrence of etomopathogenic fungi in arable soils in the UK. Field and laboratory comparisons. Biocontrol Sci. Technol. 7, 565-575.

18. Pelizza S.A., Scorsetti A.C., Fogel M.N., PachecoMarino S.G., Stenglein S.A., Cabello M.N., Lange C.E. 2015. Compatibility between entomopathogenic fungi and biorational insecticides in toxicity against Ronderosia bergi under laboratory conditions. BioControl, 60, 81-91.

19. Poprawski T.J., Majchrowicz I. 1995. Effects of herbicides on in vitro vegetative growth and sporulation of entomopathogenic fungi. Crop Prot. 14 (1), 81-87.

20. Rashid M., Baghdadi A., Sheikhi A., Pourian H-R., Gazavi M. 2010. Compatibility of Metarhizium anisopliae (Ascomycota: Hypocreales) with several insecticides. J. Plant Prot. Res. 50 (1), 22-27. 
21. Sapieha A., Miętkiewski R. 1991/1992. Wpływ inhibitorów syntezy chityny na wzrost grzybów owadobójczych in vitro. Acta Mycol. 27 (2), 189-195.

22. Tkaczuk C. 2001. Wpływ wybranych pestycydów stosowanych w ochronie sadów na wzrost grzybów owadobójczych. Biuletyn Naukowy 12, 375-383.

23. Tkaczuk C. 2008. Występowanie i potencjał infekcyjny grzybów owadobójczych w glebach agrocenoz i środowisk seminaturalnych w krajobrazie rolniczym. Wydawnictwo Akademii Podlaskiej. Rozprawa naukowa Nr 94, 160s.

24. Tkaczuk C., Krzyczkowski T., Głuszczak B., Król A. 2012. Wpływ wybranych środków ochrony roślin na wzrost kolonii i kiełkowanie zarodników owadobójczego grzyba Beauveria bassiana (Bals.) Vuill. Prog. Plant Prot./Post. Ochr. Roślin. 52(4), 969-974.
25. Tkaczuk C., Majchrowska- Safaryan A., Zawadzka M. 2013. Wpływ spinosadu oraz wybranych insektycydów syntetycznych na wzrost grzybów entomopatogenicznych w warunkach in vitro. J. Res. Appl. Agric. Eng. 58 (4), 194-198.

26. Tkaczuk C., Miętkiewski R. 2001. The growth of Hirsutella aphidis Petch - less-known pathogen of aphids - on media containing pesticides. Aphids and Other Hemipterous Insects 8, 423-428.

27. Tkaczuk C., Miętkiewski R. 2005. Effect of selected pesticides on the growth of fungi from Hirsutella genus isolated from phytophagous mites. J. Plant Prot. Res. 45 (3), 171-179.

28. Vänninen I., Hokkanen H. 1988. Effect of pesticides on four species of entomopathogenic fungi in vitro. Ann. Agric. Fen. 27, 345-353. 